\title{
Effect of forest biomass as bedding material on compost-bedded pack performance, microbial content, and behavior of nonlactating dairy cows
}

\author{
L. Llonch, L. Castillejos, ${ }^{*}$ E. Mainau, X. Manteca, and A. Ferret \\ Animal Nutrition and Welfare Service, Department of Animal and Food Science, Universitat Autònoma de Barcelona, 08193 Bellaterra, Spain
}

\begin{abstract}
Compost-bedded pack (CBP) barns for dairy cows mainly use sawdust as bedding material. The objective of this study was to compare forest biomass to sawdust as bedding material for CBP. Variables evaluated included CBP moisture, temperature and C:N ratio, bedding microbial counts, and behavior and welfare measures of nonlactating cows. The experimental design was a crossover where two 11-wk periods were performed. Treatments were CBP with sawdust (CBP-S) as a control treatment and CBP with forest biomass (CBP-FB) as the experimental bedding material. Weather conditions, intake, CBP temperature, CBP moisture, and welfare assessment were measured during the entire periods. We took CBP samples for microbiological analysis and video recordings for animal behavior assessment in wk 11 of each period. The CBP management was the same in both treatments and periods, based on twice-daily tilling at a $30 \mathrm{~cm}$ depth, and the addition of $0.8 \mathrm{~kg} / \mathrm{m}^{2}$ of new bedding material per day. Ambient temperature and environmental humidity were $9.1^{\circ} \mathrm{C}$ and $82.5 \%$ in period 1 , and $13.2^{\circ} \mathrm{C}$ and $75.3 \%$ in period 2. Average DMI and water consumption were $17.4 \pm 0.86 \mathrm{~kg} / \mathrm{d}$ and $50.9 \pm 7.84 \mathrm{~L} / \mathrm{d}$ in period 1 , and $16.3 \pm 0.96 \mathrm{~kg} / \mathrm{d}$ and $56.3 \pm 8.02 \mathrm{~L} / \mathrm{d}$ in period 2. Average of temperature, moisture, and C:N ratio of $\mathrm{CBP}$ were $32.2^{\circ} \mathrm{C}, 63.6 \%$, and $44: 1$ in CBP-S, and $24.3^{\circ} \mathrm{C}, 66.4 \%$, and $35: 1$ in $\mathrm{CBP}-\mathrm{FB}$, respectively. Temperature was higher in CBP-S than in CBP-FB, and in period 2 compared with period 1 . Moisture was higher in CBP-FB than in CBP-S in period 1, but did not differ between treatments in period 2. The C:N ratio was higher in CBP-S than in CBP-FB in both periods. Total bacteria count and Bacillus spp. were similar between treatments. Klebsiella spp. counts in CBP-S were higher than in CBP-FB, and Streptococcus spp. and yeasts and fungi counts in CBP-S were lower than in CBP-FB. Total coliforms, Escherichia coli, and
\end{abstract}

Received March 10, 2020.

Accepted June 23, 2020.

*Corresponding author: lorena.castillejos@uab.es
Staphylococcus aureus counts in CBP-S were higher than in CBP-FB in period 1, but did not differ between treatments in period 2. No differences were detected in lying time $(15.5 \mathrm{~h} / \mathrm{d})$, and time needed to lie down was higher in CBP-FB (5.3 s) than in CBP-S (4.6 s). We found that $\mathrm{CBP}$ performance and cow comfort in CBPFB were lower than in CBP-S, but microbial counts of some species were better controlled in CBP-FB than in CBP-S.

Key words: bacterial count, bedding material, compost-bedded pack performance, cow comfort, lying behavior

\section{INTRODUCTION}

A compost-bedded pack (CBP) barn is a globally established loose-housing system for dairy cows that has increased in popularity. Improvements in health, welfare and performance of cows, ease of farm chores, and reduced building costs have been described in comparison to freestall and tiestall facilities (Barberg et al., 2007a; Black et al., 2013; Fernández et al., 2020). With proper management, involving twice-daily tilling and periodic bedding addition, the composting process allows manure and urine to be stored for longer periods (Barberg et al., 2007b; Janni et al., 2007; Black et al., 2013). Tilling incorporates manure and air in the pack, which promotes aerobic microbiological activity, heats the pack, and dries the lying surface for cattle to lie on (Shane et al., 2010). Bedding addition increases the water-holding capacity of the pack to control CBP moisture. Cow density, ambient weather conditions, air flow, and cow hygiene are major factors that affect the need for new bedding addition (Barberg et al., 2007b; Janni et al., 2007). Compost-bedded pack temperatures above $55^{\circ} \mathrm{C}$ maximize sanitization (Stentiford, 1996), but CBP temperatures observed by Barberg et al. (2007b), Klaas et al. (2010), and Black et al. (2013) did not reach the required bedding sanitization level. The lack of material sanitized in the CBP indicates that it is more of a semicomposting system that does not run the full cycle of the composting process, which has target temperatures between 45 and $55^{\circ} \mathrm{C}$. 
Though farmers are satisfied with cow comfort, longevity, and ease of chores, their main concern is the cost and limited supply of bedding material (Barberg et al., 2007b). Bedding material with good physical structure, good water absorption capacity, less than $25 \%$ initial moisture, and less than $2.5 \mathrm{~cm}$ particle size that can withstand stirring with mechanical equipment appears to be the best option for these housing systems (Shane et al., 2010). Fine dry wood shavings or sawdust are the most commonly used bedding material for CBP because they are thought to improve handling, mixing, aeration, and biological activity due to their large surface areas (Barberg et al., 2007b; Janni et al., 2007).

Bacterial counts and type of bacteria in the bedding material are positively correlated with bacterial counts on the teat ends (Hogan and Smith, 1997; Zdanowicz et al., 2004) and the rates of clinical mastitis in lactating dairy cows (Hogan et al., 1989). Bacterial counts in CBP bedding are high, but the expected effects on SCC, bulk tank SCC, and clinical mastitis have not been seen (Barberg et al., 2007a; Black et al., 2014; Eckelkamp et al., 2016a).

Animal welfare in a bedded pack barn is mainly improved by more space, a softer lying surface, and easier experience for cows to get up and lie down when compared with a freestall barn (Galama et al., 2011). Lying time is a measurable and usable indicator of animal welfare (Fregonesi and Leaver, 2001). Cattle movements of lying down and getting up are affected by their environment, including the lying surface and housing system (Lidfors, 1989). Observations of lying behavior with CBP similar to or better than those reported in other facilities indicate that CBP can be an adequate system for dairy cows (Endres and Barberg, 2007; Eckelkamp et al., 2014; Fernández et al., 2020).

There is a lack of knowledge about other types of materials that could potentially work as well as sawdust in this type of housing system (Barberg et al., 2007b; Shane et al., 2010). Forest biomass is a byproduct resulting from forest cleaning. There is recent interest in finding other uses for this byproduct, such as bedding for livestock. The objective of this study was to compare forest biomass to sawdust as bedding material for CBP dairy barns. Variables evaluated included CBP moisture, temperature and $\mathrm{C}: \mathrm{N}$ ratio, bedding microbial counts, and cow behavior and welfare measures.

\section{MATERIALS AND METHODS}

\section{Housing, Experimental Design, Animals, and Diet}

Animal procedures were approved by the Institutional Animal Care and Use Committee (reference CEEAH 9963) of the Universitat Autònoma de
Barcelona (Spain) in accordance with the European directive 2010/63/EU. The study was conducted on the Experimental Farm of the Universitat Autònoma de Barcelona between October 2016 and March 2017. Eight dry nonpregnant and nonlactating Holstein cows $(795 \pm 19.7 \mathrm{~kg}$ of BW) were individually allocated in roofed concrete floor pens $\left(12.5 \mathrm{~m}^{2}\right)$. Each pen was divided in 2 areas; half of the pen contained the feeding area, which was equipped with a feed bunk and a water trough, and the other half contained the resting area. Pens were separated by a metal fence that allowed contact between animals. Cows were randomly assigned to 1 of 2 treatments in a crossover design with 4 cows per treatment. The study was performed in two 11-wk periods (period 1 and period 2), with a 4-wk washout period between them. Cows were cleaned outside of the barn and the dirt brushed off at the beginning of the periods. Treatments were (1) CBP with bedding material of sawdust (CBP-S) and (2) CBP with bedding material of forest biomass (CBP-FB). Forest biomass was mostly composed of tree bark and vegetal fibers from a Mediterranean forest. During the washout period, cows lied on traditional bedding of wood shavings. At the beginning of each period, pens were filled with $30 \mathrm{~cm}$ of the new bedding material. The CBP was tilled twice daily (1000 and $1700 \mathrm{~h}$ ) at $30 \mathrm{~cm}$ depth with a rototiller, and an average of $0.8 \mathrm{~kg} / \mathrm{m}^{2}$ of new bedding material per day was added in each pen before tilling when pen CBP moisture was greater than $60 \%$. The average amount of new bedding material added was 7.8 $\mathrm{kg} /$ pen per day in CBP-S and $7.9 \mathrm{~kg} / \mathrm{pen}$ per day in CBP-FB. Both CBP were completely removed at the end of wk 11 of each period, which was considered the sampling week. Daily ambient temperature and environmental humidity were obtained from 2 data loggers located in the barn (UX100-003, Hobo, Algete-Madrid, Spain). The Temperature humidity index was calculated according to NRC (1971) and expressed per week and period. Cows were weighed the first and the last day of each period with a scale (AG500/E, TRUSTET PROII version 3.2., l'Hospitalet de Llobregat, Spain). Cows were fed ad libitum with a TMR made up of $74.6 \%$ alfalfa hay, $16.6 \%$ corn grain, $6.7 \%$ soybean meal, $1.7 \%$ molasses, and $0.4 \%$ of a vitamin-mineral premix. Diet, offered twice daily (0900 $\mathrm{h}$ and $1600 \mathrm{~h}$ ), was formulated to contain $1.3 \mathrm{Mcal} / \mathrm{kg}$ of DM. Its chemical composition was as follows: $14.9 \% \mathrm{CP}$, determined by the Kjeldahl procedure (AOAC, 1990; 976.05), and 38.5\% NDF, determined in accordance with the procedure of Van Soest et al. (1991) using a thermostable $\alpha$-amylase and sodium sulfite. Dry matter intake and water consumption were recorded by means of feed bunks mounted on waterproof digital platform scales (model DI-160, DIGI I's Ltd., Maesawa-cho, Isawa-gun, Iwate, Japan), 
and drinking cups fitted with flow meters (B98.32.50, Invensys model 510 C, Tashia S.L., Artesa de Segre, Spain).

\section{Sampling and Measurements}

Raw bedding material samples were collected at the beginning and the middle of each period and stored at $4^{\circ} \mathrm{C}$ until analysis. Moisture was measured in a $200-\mathrm{g}$ sample and determined using a forced-air oven at $103^{\circ} \mathrm{C}$ for $24 \mathrm{~h}$; apparent density was measured by weighing material contained in a $100-\mathrm{mL}$ test tube; particle size was measured with an electromagnetic sieve shaker (RP 200N, CISA Cedaceria Industrial S. L., Barcelona, Spain); initial microbiology counts were analyzed using microbial culture methods. Daily CBP temperature and weekly CBP moisture were measured in the feeding and resting areas of each pen. The CBP temperature was measured at $15 \mathrm{~cm} \mathrm{CBP}$ depth with a thermometer and a $15-\mathrm{cm}$ probe $\left(\mathrm{K} / \mathrm{JR}-200+800^{\circ} \mathrm{C}\right.$, Ventix, Sant Adrià de Besós, Spain). The CBP moisture was measured with $200 \mathrm{~g}$ of bedded material samples that were taken at $15 \mathrm{~cm}$ CBP depth with a spatula, introduced into tared aluminum trays, and dried at $103^{\circ} \mathrm{C}$ for $24 \mathrm{~h}$ in a forced-air oven. Compost-bedded pack samples were collected in wk 11 from feeding and resting area (obtaining a composite sample of each pen) and stored at $-18^{\circ} \mathrm{C}$ until analysis. At the moment of analysis, samples were defrosted at room temperature. They were then used to determine ash (AOAC, 1990; 942.05) and nitrogen content (AOAC, 1990; 976.05) to estimate the $\mathrm{C}: \mathrm{N}$ ratio in accordance with Zucconi and de Bertoldi (1987), as well as to analyze microbiology counts with microbial culture methods.

\section{Behavior and Welfare Measurements}

Animal behavior was video-recorded for $24 \mathrm{~h}$ on 2 consecutive days of the sampling wk using a digital color camera (model VIVOTEK IP7142, VIVOTEK INC., Chung- HO, Taipei County, Taiwan) installed in each pen and a digital video-recording device (model VS-101P VioStor NVR, QNAP Systems Inc., Xizhi City, Taipei County, Taiwan). An infrared light with photoelectric cells (model 2020, Dennard, Fleet, UK) was set up in each pen to allow video-recording at night $(\lambda=830 \mathrm{~nm}$ and $500 \mathrm{~W})$. On each recording day, animals were observed for $8 \mathrm{~h}$ divided into four 2-h time intervals (0100-0300, 0700-0900, 1300-1500, and 1900-2100 h) according to the circadian rhythm of cows and avoiding the daily routines of the farm management that could have altered normal behavior. Time sampling method, carried out for 5 min at 20-min intervals, and focal sampling were performed using the same daily observation. Observations were performed by a single observer. Windows media player (Windows 7, Microsoft Corp., Redmond, WA) software was used to watch videos and Microsoft Excel (Microsoft Office 2007, Microsoft Corp.) software was used to record all the observations during assessment. Behaviors observed were previously defined (Table 1). In the time-sampling method, evaluation was composed of 2 parts: posture and activity. The sum of the 4 lying positions shows the lying time, extrapolated in hours per day, and each lying position was expressed as a percent of total lying time. Activity behaviors were extrapolated in hours per day. In focal sampling, the behaviors recorded were lying down and getting up movements. Lying down and getting up movements were expressed in seconds, and failed attempts in number of attempts.

Animal welfare was assessed weekly. Both sides of the cow were assessed with scored measurements from a maximum of 1 to $2 \mathrm{~m}$ distance. The assessment was performed by a single observer. Animal welfare assessment was based on the Welfare Quality Project (2009). The following measures were used: BCS (score $0=$ normal, score 1 = very lean, and score 2 = very fat), cleanliness of hind quarters and lower hind legs (score 0 $=$ clean, and score $2=$ dirty), lameness $($ score $0=$ not lame, score $1=$ lame, and score 2 = severely lame), integument alterations (score $0=$ no alteration, score $1=$ moderate alteration with hairless patches, and score 2 $=$ severe alteration with lesions or swelling), and nasal and ocular discharge, hampered respiration, diarrhea, and vulvar discharge (score $0=$ absence, and score 2 $=$ presence). These measures are classified in different welfare principles: good feeding (BCS), good housing (cleanliness of hind quarters and lower hind legs), and good health (lameness, integument alterations, nasal and ocular discharge, hampered respiration, diarrhea, and vulvar discharge). Data were analyzed as proportions of scores 1 and 2 of each measure.

\section{Statistical Analysis}

Cow was considered the experimental unit in the statistical analysis. A power analysis was conducted to calculate the number of replicates needed to give a reliable outcome. This analysis was performed using the standard deviation of some variables observed in previous experiments under similar experimental conditions. The normality study of variables was assessed with the UNIVARIATE procedure of SAS (v. 9.3; SAS Institute Inc., Cary, NC). The CBP temperature, CBP moisture, $\mathrm{CBP} C: \mathrm{N}$ ratio, and $\mathrm{CBP}$ microbiology data were analyzed using the MIXED procedure of SAS. The model 
Table 1. Ethogram of behaviors assessed

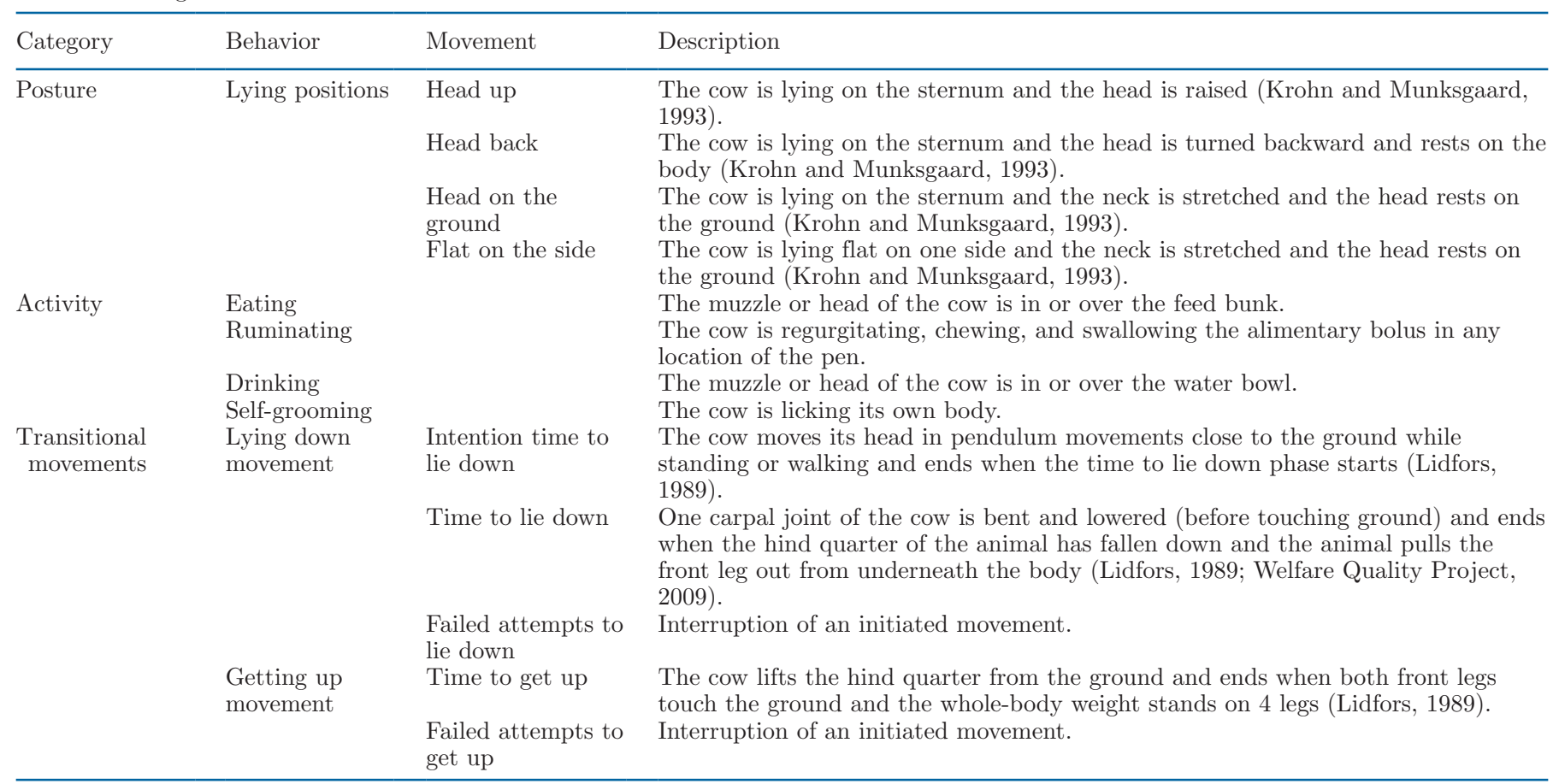

contained the fixed effects of treatment, period, and treatment $\times$ period interaction, and the random effect of cow nested within sequence, where sequence was the order in which treatment was applied to the experimental unit. Repeated measure statement of day was used for CBP temperature. The choice of the best covariance structure was based on fit statistics (Littell et al., 1998), using compound symmetry as covariance structure. Behavior data were nonparametric and were analyzed using the GLIMMIX procedure of SAS according to their respective distributions. The model contained the fixed effects of treatment, period, and treatment $\times$ period interaction, and the random effects of cow nested within sequence and time of day. Repeated measure statement of day was used for all behavioral variables, and as covariance structure, we used unstructured banded for head back lying position, variance components for flat on the side lying position and drinking behavior, and compound symmetry for the remaining variables. The Tukey multiple comparison test was applied to conduct mean separation across treatments and periods in parametric and nonparametric data. The cleanliness of cows, as a dichotomous variable, was assessed by a Chi-squared test. Significance was declared at $P<$ 0.05 and tendency was discussed at $P<0.10$. Kappa coefficient of concordance, as a measure of agreement that is corrected for chance, was calculated for each behavior to determine intra-observer reliability using the FREQ procedure of SAS. We compared 2 repeated observations made on 2 separate occasions by the same observer on $1 \mathrm{~d}$ with 4 cows. The average Kappa coefficient was 0.851. Specifically, the coefficients for each behavior were 0.729 for lying down movement, 0.729 for getting up movement, 0.978 for posture behaviors, and 0.968 for activity behaviors. These coefficients would indicate an almost perfect agreement according to the classification given by Landis and Koch (1977).

\section{RESULTS}

The moisture, apparent density and proportion of particle size equal to or less than $2 \mathrm{~mm}$ for raw bedding materials were $10.2 \pm 0.77 \%, 182 \pm 6.3 \mathrm{~g} / \mathrm{L}$, and 53.3 $\pm 7.08 \%$, respectively, for sawdust and $32.1 \pm 5.25 \%$, $240 \pm 16.2 \mathrm{~g} / \mathrm{L}$, and $24.3 \pm 4.78 \%$, respectively, for forest biomass. Counts of microorganisms for each raw bedding material are shown in Table 2. Raw sawdust microorganism counts were lower than raw forest biomass microorganism counts, except for Escherichia coli and Staphylococcus aureus, which were $2.00 \log _{10} \mathrm{cfu} / \mathrm{g}$ in both materials (data not shown). At the end of the experiment, average BW was $850 \pm 18.1 \mathrm{~kg}$. Average DMI and water consumption were $17.4 \pm 0.86 \mathrm{~kg} / \mathrm{d}$ and $50.9 \pm 7.84 \mathrm{~L} / \mathrm{d}$ in period 1 , and $16.3 \pm 0.96 \mathrm{~kg} / \mathrm{d}$ and $56.3 \pm 8.02 \mathrm{~L} / \mathrm{d}$ in period 2 .

Weather conditions across the experiment are presented in Figure 1. In period 1, we observed that ambient temperature progressively decreased from 19.5 to $9.1^{\circ} \mathrm{C}$, 
Table 2. Microorganism counts resulting from microbial culture in raw bedding materials

\begin{tabular}{|c|c|c|c|c|c|c|}
\hline \multirow{2}{*}{$\begin{array}{l}\text { Microorganism count, } \\
\log _{10} \mathrm{cfu} / \mathrm{g}\end{array}$} & \multicolumn{2}{|c|}{ Bedding material } & \multirow[b]{2}{*}{ SEM } & \multicolumn{3}{|c|}{$P$-value ${ }^{1}$} \\
\hline & Sawdust & Forest biomass & & $\mathrm{T}$ & $\mathrm{P}$ & $\mathrm{T} \times \mathrm{P}$ \\
\hline Total bacteria count & 4.00 & 7.47 & 0.517 & 0.003 & NS & NS \\
\hline Total coliforms & 2.00 & 5.31 & 0.710 & 0.010 & NS & NS \\
\hline Klebsiella spp. & 2.00 & 4.47 & 0.469 & 0.006 & NS & NS \\
\hline Streptococcus spp. & 2.00 & 2.84 & 0.383 & 0.093 & NS & NS \\
\hline Bacillus spp. & 3.05 & 4.92 & 0.302 & 0.025 & NS & NS \\
\hline Yeasts and fungi & 2.25 & 5.63 & 0.460 & 0.002 & NS & NS \\
\hline
\end{tabular}

${ }^{1} \mathrm{~T}=$ treatment effect; $\mathrm{P}=$ period effect; $\mathrm{T} \times \mathrm{P}=$ treatment $\times$ period interaction effect.

and environmental humidity ranged between 74.1 and $90.4 \%$. In period 2 , ambient temperature progressively increased from 5.9 to $14.1^{\circ} \mathrm{C}$, and humidity ranged between 61.6 and $87.3 \%$. In the sampling week, average ambient temperature and environmental humidity were $9.1^{\circ} \mathrm{C}$ and $82.5 \%$ in period 1 , and $13.2^{\circ} \mathrm{C}$ and $75.3 \%$ in period 2, respectively. Temperature humidity index was below heat stress thresholds, with all values below 68 (data not shown).

Temperature, moisture, and C:N ratio of CBP treatments during sampling week are presented in Table 3. In CBP temperature, we detected treatment and period effects $(P=0.001)$. Temperature of CBP-S was higher than CBP-FB temperature, and CBP temperature in period 1 was lower than CBP temperature in period 2 . We detected a treatment $\times$ period interaction effect in CBP moisture $(P=0.004)$; CBP-S moisture was lower than CBP-FB moisture in period 1 , whereas period 2 presented no differences between treatments. A treatment $\times$ period interaction $(P=0.005)$ affected the $\mathrm{C}: \mathrm{N}$ ratio; it was greater in CBP-S than in CBP-FB in both periods, and greater in period 1 than in period 2 for CBP-S, but not for CBP-FB.
In Figure 2, $\mathrm{CBP}$ temperature and $\mathrm{CBP}$ moisture across the experiment are shown. In both treatments in period 1, we observed a small increase of CBP temperature from $40^{\circ} \mathrm{C}$ in the first weeks, followed by a decrease until wk 7 , from which point it remained quite stable until the end of the period. However, CBP-S temperature values were always above CBP-FB temperature. In both treatments in period 2 , we observed an increase of $\mathrm{CBP}$ temperature from $15^{\circ} \mathrm{C}$, followed by a brief decrease and stabilization at $25^{\circ} \mathrm{C}$ until the middle of the period. It increased again toward the end of the period, then stabilized, before finally decreasing. These changes were greater in CBP-S than in CBP-FB, and once again CBP-S temperature values were always above CBP-FB temperature values. In both treatments and periods, we observed an increase in CBP moisture from the beginning to the middle of the period and a stabilization of between 60 and $70 \%$ until the end of the period. However, in period 1, CBP-S moisture values were always below CBP-FB moisture, whereas in period 2, CBP-S moisture values were below CBP-FB moisture until wk 4, performing equally until the end of this period.

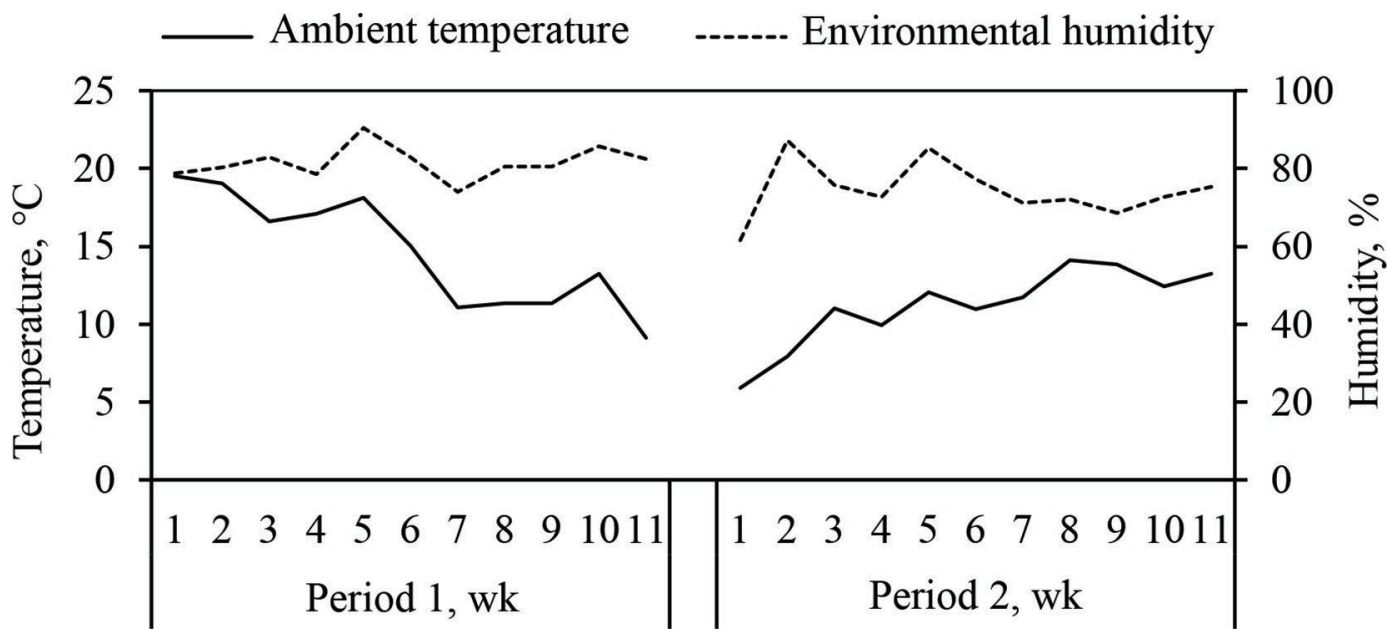

Figure 1. Weather conditions across the experiment. 
Table 3. Effect of bedding materials on temperature, moisture, and C:N ratio of compost-bedded pack ${ }^{1}$ in sampling week

\begin{tabular}{|c|c|c|c|c|c|c|c|c|}
\hline \multirow[b]{2}{*}{ Item } & \multicolumn{2}{|c|}{ Period 1} & \multicolumn{2}{|c|}{ Period 2} & \multirow[b]{2}{*}{ SEM } & \multicolumn{3}{|c|}{$P$-value ${ }^{2}$} \\
\hline & CBP-S & CBP-FB & CBP-S & CBP-FB & & $\mathrm{T}$ & $\mathrm{P}$ & $\mathrm{T} \times \mathrm{P}$ \\
\hline Temperature, ${ }^{\circ} \mathrm{C}$ & 29.8 & 21.4 & 34.6 & 27.2 & 1.47 & 0.001 & 0.001 & NS \\
\hline Moisture, \% & $64.3^{\mathrm{b}}$ & $69.6^{\mathrm{a}}$ & $62.9^{\mathrm{b}}$ & $63.1^{\mathrm{b}}$ & 1.09 & 0.002 & 0.001 & 0.004 \\
\hline C:N ratio & $47.8^{\mathrm{a}}$ & $35.1^{\mathrm{c}}$ & $40.2^{\mathrm{b}}$ & $34.5^{\mathrm{c}}$ & 1.11 & 0.001 & 0.002 & 0.005 \\
\hline
\end{tabular}

${ }^{\mathrm{a}-\mathrm{c}}$ Means within a row with different superscripts differ $(P<0.05)$.

${ }^{1} \mathrm{CBP}-\mathrm{S}=$ compost-bedded pack of sawdust treatment; CBP-FB $=$ compost-bedded pack of forest biomass treatment.

${ }^{2} \mathrm{~T}=$ treatment effect; $\mathrm{P}=$ period effect; $\mathrm{T} \times \mathrm{P}=$ treatment $\times$ period interaction effect.

Microorganism counts of CBP treatments are presented in Table 4. Treatments did not affect total bacteria count $(P=0.433)$. We observed a treatment effect $(P=0.022)$ in Klebsiella spp., where CBP-S counts were higher than CBP-FB counts. We detected treatment and period effects in Streptococcus spp. ( $P$ $=0.020$ and $P=0.018$, respectively) and in yeasts and fungi $(P=0.001$ and $P=0.005$, respectively), where counts in CBP-S were lower than in CBP-FB, and counts in period 1 were higher than in period 2 . We detected a period effect in Bacillus spp. $(P=0.018)$, where counts were lower in period 1 than in period 2 . Finally, we detected a treatment $\times$ period interaction in total coliforms $(P=0.001), E$. coli $(P=0.003)$, and $S$. aureus $(P=0.001)$, where CBP-S counts in period
1 were higher than in CBP-FB, but period 2 presented no differences between treatments.

Treatments did not affect lying time and lying positions (Table 5). They also did not affect feeding behaviors (eating, ruminating, and drinking; Table 6), but time spent eating tended $(P=0.074)$ to be higher in period 1 than in period 2 ( 3.2 vs. $2.4 \mathrm{~h} / \mathrm{d} \pm 0.49$; data not shown), and time spent drinking tended $(P$ $=0.054)$ to be lower in period 1 than in period $2(0.1$ vs. $0.2 \mathrm{~h} / \mathrm{d} \pm 0.05$; data not shown). Cows spent more time expressing self-grooming behaviors in CBP-FB than in CBP-S (Table 6; $P=0.042$ ). As for lying down movement, we detected a treatment effect (Table 7; $P$ $=0.012)$ in time to lie down; cows on CBP-FB spent more time than cows on CBP-S. We detected a period

$\multimap$ CBP-S Temperature $\longrightarrow$ CBP-FB Temperature $\quad--$--- CBP-S Moisture $\quad-\bullet--$ CBP-FB Moisture

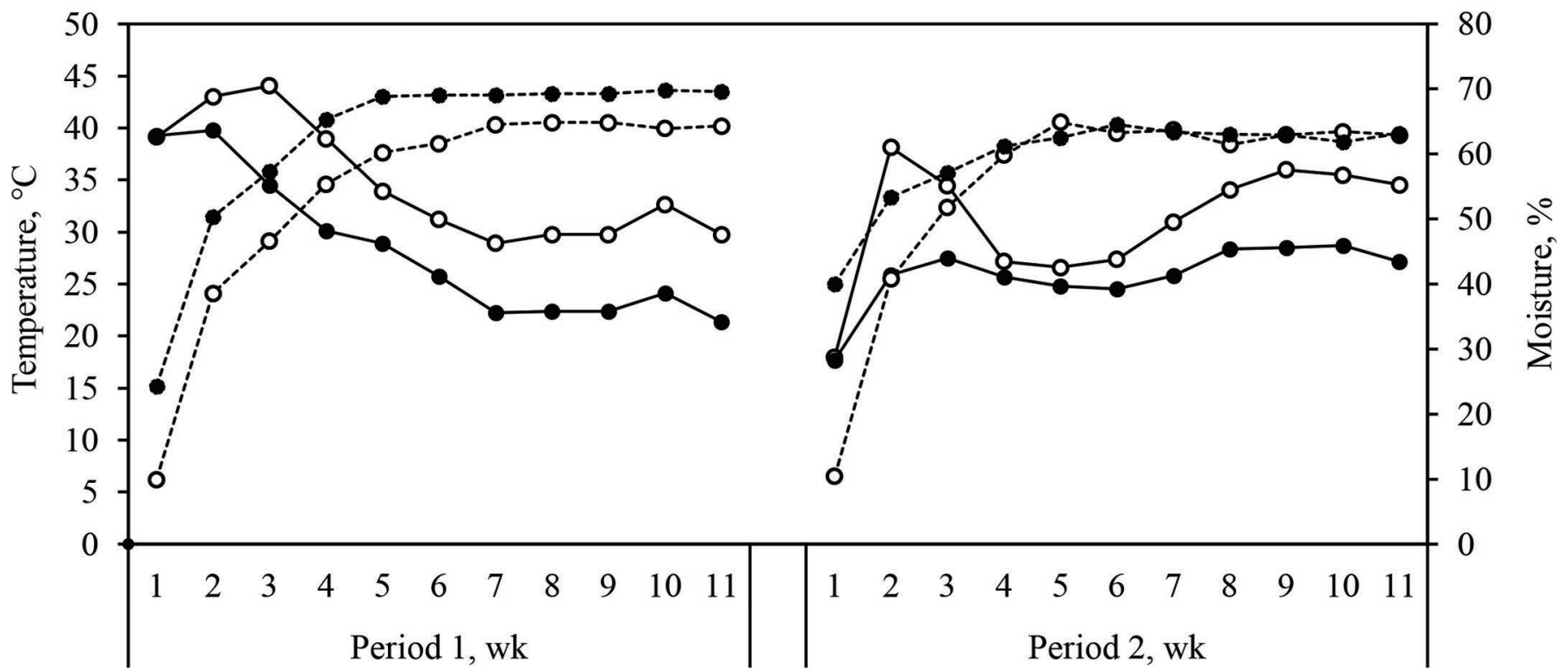

Figure 2. Temperature and moisture of compost-bedded pack (CBP) with sawdust (CBP-S) or forest biomass (CBP-FB) across the experiment. 
Table 4. Effect of bedding materials on microorganism counts of compost-bedded pack ${ }^{1}$ in sampling week

\begin{tabular}{|c|c|c|c|c|c|c|c|c|}
\hline \multirow{2}{*}{$\begin{array}{l}\text { Microorganism count, } \\
\log _{10} \mathrm{cfu} / \mathrm{g}\end{array}$} & \multicolumn{2}{|c|}{ Period 1} & \multicolumn{2}{|c|}{ Period 2} & \multirow[b]{2}{*}{ SEM } & \multicolumn{3}{|c|}{$P$-value ${ }^{2}$} \\
\hline & CBP-S & CBP-FB & CBP-S & CBP-FB & & $\mathrm{T}$ & $\mathrm{P}$ & $\mathrm{T} \times \mathrm{P}$ \\
\hline Total bacteria count & 8.94 & 8.84 & 8.81 & 9.17 & 0.212 & NS & NS & NS \\
\hline Total coliforms & $7.29^{\mathrm{a}}$ & $5.27^{\mathrm{c}}$ & $5.63^{\mathrm{bc}}$ & $5.89^{\mathrm{b}}$ & 0.134 & 0.001 & 0.001 & 0.001 \\
\hline Escherichia coli & $6.00^{\mathrm{a}}$ & $4.38^{\mathrm{b}}$ & $5.09^{\mathrm{ab}}$ & $5.79^{\mathrm{a}}$ & 0.342 & NS & NS & 0.003 \\
\hline Klebsiella spp. & 5.25 & 4.35 & 5.39 & 5.01 & 0.298 & 0.022 & NS & NS \\
\hline Streptococcus spp. & 7.35 & 7.99 & 7.26 & 7.34 & 0.189 & 0.020 & 0.018 & NS \\
\hline Staphylococcus aureus & $7.92^{\mathrm{a}}$ & $6.20^{\mathrm{c}}$ & $6.87^{\mathrm{bc}}$ & $7.74^{\mathrm{ab}}$ & 0.262 & 0.062 & NS & 0.001 \\
\hline Bacillus spp. & 5.91 & 6.29 & 6.99 & 7.08 & 0.412 & NS & 0.018 & NS \\
\hline Yeasts and fungi & 4.86 & 5.87 & 4.37 & 5.35 & 0.180 & 0.001 & 0.005 & NS \\
\hline
\end{tabular}

effect in getting up movement (Table $7 ; P=0.008$ ); failed attempts to get up were higher in period 1 than in period 2 (data not shown).

Treatments did not affect good feeding and good health measures (data not shown). With regard to good housing, we did not detect any difference in the dirty score of cows' cleanliness measures, neither in upper hind legs (44 vs. $50 \%$ for CBP-S and CBP-FB, respectively; $P=0.723$; data not shown) nor in lower hind legs (56 vs. $75 \%$ for CBP-S and CBP-FB, respectively; $P=0.264$; data not shown).

\section{DISCUSSION}

The present study was designed to monitor CBP performance and CBP microbial content of 2 bedding materials as CBP, and to know their effects on individual animal behavior and welfare indicators. With this purpose in mind, nonlactating cows were individually allocated to avoid daily routines in order to assess individual indicators and the associated pack

Table 5. Effect of bedding materials on time spent in posture behaviors in sampling week

\begin{tabular}{|c|c|c|c|c|c|c|}
\hline \multirow[b]{2}{*}{ Posture } & \multicolumn{2}{|c|}{ Treatment $^{1}$} & \multirow[b]{2}{*}{ SEM } & \multicolumn{3}{|c|}{$P$-value ${ }^{2}$} \\
\hline & CBP-S & CBP-FB & & $\mathrm{T}$ & $\mathrm{P}$ & $\mathrm{T} \times \mathrm{P}$ \\
\hline $\begin{array}{l}\text { Lying time, } \mathrm{h} / \mathrm{d} \\
\text { Lying positions, \% }\end{array}$ & 15.5 & 15.5 & 0.94 & NS & NS & NS \\
\hline Head up & 88.0 & 84.7 & 6.17 & NS & NS & NS \\
\hline Head back & 10.3 & 11.2 & 3.97 & NS & NS & NS \\
\hline Head on the ground & 1.2 & 3.7 & 1.87 & NS & NS & NS \\
\hline Flat on the side & 0.5 & 0.4 & 1.73 & NS & NS & NS \\
\hline
\end{tabular}

${ }^{1} \mathrm{CBP}-\mathrm{S}=$ compost-bedded pack of sawdust treatment; $\mathrm{CBP}-\mathrm{FB}=$ compost-bedded pack of forest biomass treatment.

${ }^{2} \mathrm{~T}=$ treatment effect; $\mathrm{P}=$ period effect; $\mathrm{T} \times \mathrm{P}=$ treatment $\times$ period interaction effect. characteristics. We were aware of the differences in diet composition, DMI, and water consumption between nonlactating and lactating cows, as well as the differences in their manure yield and urine excretion that could stress the compost barn system in different ways. However, we assume that these factors could have affected the magnitude but not the type of responses when comparing forest biomass and sawdust.

Weather conditions, specifically ambient temperature, affect $\mathrm{CBP}$ performance. Ambient temperature is a predictor of $\mathrm{CBP}$ temperature and $\mathrm{CBP}$ moisture. The CBP temperature increases as ambient temperature increases (Black et al., 2013; Eckelkamp et al., 2014), and CBP moisture decreases as ambient temperature increases (Eckelkamp et al., 2014). In the present study, we observed how the comparison between ambient temperature and CBP temperature followed the same pattern in both treatments. In both treatments and periods, the increase in CBP moisture in the first weeks could be explained by the fact that the composting process was still not established. However, from wk 5 until the end of each period, CBP moisture stabilized with higher values when ambient tempera-

Table 6. Effect of bedding material on times spent in activity behaviors in sampling week

\begin{tabular}{lccccccc}
\hline & \multicolumn{2}{c}{ Treatment $^{1}$} & & \multicolumn{3}{c}{$P$-value $^{2}$} \\
\cline { 2 - 3 } \cline { 6 - 8 } Activity, h/d & CBP-S & CBP-FB & SEM & T & P & T $\times$ P \\
\hline Eating & 3.1 & 2.5 & 0.49 & NS & 0.074 & NS \\
Ruminating & 7.5 & 6.9 & 0.72 & NS & NS & NS \\
Drinking & 0.1 & 0.1 & 0.05 & NS & 0.054 & NS \\
Self-grooming & 0.1 & 0.3 & 0.06 & 0.042 & NS & NS \\
\hline
\end{tabular}

${ }^{1} \mathrm{CBP}-\mathrm{S}=$ compost-bedded pack of sawdust treatment; $\mathrm{CBP}-\mathrm{FB}=$ compost-bedded pack of forest biomass treatment.

${ }^{2} \mathrm{~T}=$ treatment effect; $\mathrm{P}=$ period effect; $\mathrm{T} \times \mathrm{P}=$ treatment $\times$ period interaction effect. 
Table 7. Effect of bedding material on times spent in transitional movements in sampling week

\begin{tabular}{|c|c|c|c|c|c|c|}
\hline \multirow[b]{2}{*}{ Item } & \multicolumn{2}{|c|}{ Treatment $^{1}$} & \multirow[b]{2}{*}{ SEM } & \multicolumn{3}{|c|}{$P$-value ${ }^{2}$} \\
\hline & CBP-S & CBP-FB & & $\mathrm{T}$ & $\mathrm{P}$ & $\mathrm{T} \times \mathrm{P}$ \\
\hline \multicolumn{7}{|l|}{ Lying down movement } \\
\hline Intention time to lie down, $\mathrm{s}$ & 35.5 & 33.7 & 2.32 & NS & NS & NS \\
\hline Time to lie down, s & 4.6 & 5.3 & 0.26 & 0.012 & NS & NS \\
\hline Failed attempts to lie down, no. & 0.4 & 0.5 & 0.57 & NS & NS & NS \\
\hline \multicolumn{7}{|l|}{ Getting up movement } \\
\hline Time to get up, s & 5.2 & 5.2 & 0.64 & NS & NS & NS \\
\hline Failed attempts to get up, no. & 0.1 & 0.1 & 0.07 & NS & 0.008 & NS \\
\hline
\end{tabular}

ture decreased in period 1 . In period 2, CBP moisture stabilized with lower values when ambient temperature increased. In the sampling week, weather conditions in period 1 were colder than in period 2, and CBP temperature was lower and moisture was higher in period 1 than in period 2. These results agree with previous studies which describe that high CBP moisture and cold weather conditions dissipate the heat of the pack, thus decreasing CBP temperature and making the composting process too slow (Barberg et al., 2007a; Shane et al., 2010; Bewley et al., 2013).

The literature has reported $\mathrm{CBP}$ temperature means of $42.5,34.2$, and $45.2^{\circ} \mathrm{C}$, and CBP moisture means of 52.7, 56.1, and 59.9\% (Barberg et al., 2007a; Black et al., 2013; Eckelkamp et al., 2016b). Almost all cited values were inside recommended range values for effective composting: CBP temperature, at depths of 15 to $31 \mathrm{~cm}$, ranges from 43.3 to $65.0^{\circ} \mathrm{C}$, and CBP moisture ranges from 40 to $60 \%$ (NRAES-54, 1992, Janni et al., 2007; Bewley et al., 2013). When CBP reaches temperatures between 35 and $40^{\circ} \mathrm{C}$, the microbial population is much more diverse and not as efficient at degrading CBP material (NRAES-54, 1992; Stentiford, 1996). In addition, excessive CBP moisture content may inhibit aerobic activity due to loss of interstitial integrity, or porosity (NRAES-54, 1992). In the present study, CBP temperatures were lower and $\mathrm{CBP}$ moistures were higher than the mentioned recommendations. Despite this, CBP temperatures were higher than the ambient temperature because the composting process was active, which means that microbial activity was generating heat and helping dry the pack (Shane et al., 2010). Regarding CBP performance of the treatments, we suggest that CBP-S was better than CBP-FB because CBP-S achieved higher CBP temperatures and maintained lower CBP moisture in colder weather. This could be explained by the fact that raw sawdust had a higher percentage of particle size equal to or less than 2 $\mathrm{mm}$ than raw forest biomass, as well as lower moisture content. As Shane et al. (2010) described, fundamental characteristics for a bedding material to work in a CBP include less than $2.5 \mathrm{~cm}$ particle size and less than $25 \%$ initial moisture. Conversely, the $\mathrm{C}: \mathrm{N}$ ratio of $\mathrm{CBP}-\mathrm{S}$ was higher than CBP-FB, which demonstrated that CBP$\mathrm{S}$ was less composted. In any case, C:N ratio in both treatments showed partially composted packs according to Bewley et al. (2013), who claimed that the C:N ratio needs to be between 25:1 and 30:1 for peak composting rate. Regarding CBP performance, some improvements in forest biomass characteristics (particle size and moisture content) would enhance CBP performance in this bedding material. However, we must be careful about making changes in raw forest-biomass moisture content because CBP-FB microorganism count-results reached in this study might have been modified.

The greater total bacterial count and greater counts of almost all microorganism species detected in raw forest biomass versus raw sawdust could be attributed to the higher moisture content in forest biomass inducing greater microorganism growth. In contrast, the CBP microorganism counts of both treatments were not as different as in the case of the raw bedding materials. This means that managing for good composting in CBP allowed the proliferation of both pathogenic and nonpathogenic bacterial species in the pack (Barberg et al., 2007a; Petzen et al., 2009; Black et al., 2014; Eckelkamp et al., 2016b). The increase in total bacterial count in CBP with regard to the raw bedding material was greater in sawdust than in forest biomass (from 4.00 to $8.88 \log _{10} \mathrm{cfu} / \mathrm{g}$ on average, and from 7.47 to $9.01 \log _{10} \mathrm{cfu} / \mathrm{g}$ on average, respectively). This would suggest that forest biomass could control microorganism growth better than sawdust.

Coliforms are gram-negative bacteria associated with the intestinal tract and environmental mastitis (Hogan et al., 1989). Coliform counts are affected by CBP tem- 
perature and CBP moisture (Black et al., 2014; Eckelkamp et al., 2016b), but not by C:N ratio (Eckelkamp et al., 2016b). Black et al. (2014) reported that coliforms increased when CBP temperature increased and CBP moisture decreased. Eckelkamp et al. (2016b) observed an increase in coliform counts when CBP temperature increased and CBP moisture was equal to or greater than $60 \%$. Barberg et al. (2007b) also reported that coliforms increased in summer compared with winter. In the present experiment, when the ambient temperature increased in period 2 (ranging between 5.9 and $14.1^{\circ} \mathrm{C}$ ), CBP temperature was higher in CBP-S than CBP-FB, and we observed no differences in CBP moisture, which was over $60 \%$. In these conditions, treatment did not affect coliform counts. When the ambient temperature decreased in period 1 , ranging between 19.5 and $9.1^{\circ} \mathrm{C}$, treatment affected CBP temperature and was higher in CBP-S than in CBP-FB, and CBP moisture was lower in CBP-S than in CBP-FB ( $>60 \%$ in both treatments). This time, however, we detected a higher coliform count in CBP-S than CBP-FB. This could suggest that CBP moisture had a decisive role in coliform growth. When comparing periods within each treatment, higher coliform counts of CBP-FB in period 2 agreed with the aforementioned reports, while higher coliform counts of CBP-S in period 1 did not. This could suggest that in worse weather conditions and pack performance, forest biomass could control total coliform counts better than sawdust. Furthermore, in both periods, the C:N ratio of CBP-FB was lower than in CBP-S and not different between periods, whereas period affected the $\mathrm{C}: \mathrm{N}$ ratio of CBP-S (higher in period 1 than in period 2). This result contrasted with findings reported by Eckelkamp et al. (2016b), which stated that C:N ratio did not affect coliform counts.

Coliforms such as E. coli and Klebsiella spp. are potential pathogens that cause mastitis (Eberhart, 1984). Ward et al. (2002) observed that E. coli can survive and multiply optimally between 15 and $45^{\circ} \mathrm{C}$, and begin to die in temperatures above $45^{\circ} \mathrm{C}$. Black et al. (2014) found that $E$. coli counts increased when ambient temperature increased. In the present study, E. coli counts behaved as coliform counts; the growth of $E$. coli was greater in CBP-S than in CBP-FB in period 1, but not in period 2. Although E. coli counts of CBP-FB were higher in period 2 in the comparison of periods within treatments, we did not observe differences in $E$. coli counts of CBP-S. In the case of Klebsiella spp., avoiding green or wet sawdust or shavings is recommended to reduce teat-end exposure to these bacteria (Janni et al., 2007; Black et al., 2013). Lobeck et al. (2012) described a trend of higher Klebsiella counts in the summer than in the winter. However, Eckelkamp et al. (2016b) re- ported that Klebsiella spp. had no significant relationships with CBP temperature, CBP moisture, and C:N ratio. In the present study, Klebsiella spp. counts were greater in CBP-S than CBP-FB, suggesting that forest biomass could control Klebsiella spp. counts better than sawdust.

Streptococcus dysgalactiae and Streptococcus uberis are 2 well-known environmental mastitis pathogens present in the environment and bedding of the cow (Bramley et al., 1996). Streptococcus spp. grow in temperatures between 25 and $42^{\circ} \mathrm{C}$ (Hardie and Whiley, 1995), with higher counts in winter than in summer (Shane et al., 2010). Black et al. (2014) reported no effect of CBP temperature on Streptococcus spp. counts, but suggested maintaining recommended moisture levels of 50 to $60 \%$ (NRAES-54, 1992) as a strategy to limit their growth. Conversely, Eckelkamp et al. (2016b) observed a decrease in Streptococcus spp. counts when CBP temperature increased, but $\mathrm{CBP}$ moisture and $\mathrm{C}: \mathrm{N}$ ratio did not affect them. In the present experiment, CBP temperatures were inside the range of values proposed to promote Streptococcus spp. growth and, in agreement with Eckelkamp et al. (2016b), greater counts and lower CBP temperatures were found in CBP-FB compared with CBP-S in both periods. Moreover, Streptococcus spp. counts were lower in period 2 than in period 1 when the CBP temperature was greater in period 2 . In contrast to Eckelkamp et al. (2016b), however, C:N ratio could affect Streptococcus spp. counts, with lower ratios related to greater counts.

Staphylococcus aureus is a highly contagious mastitis pathogen in dairy herds (Barkema et al., 2006), and bedding can be a $S$. aureus source (Roberson et al., 1994). Staphylococcus aureus survives in temperatures between 6 and $48^{\circ} \mathrm{C}$, with an optimum temperature of $37^{\circ} \mathrm{C}$ (Vandenbosch et al., 1973). The wide temperature survival range combined with the additional CBP heat generation indicates that Staphylococcus spp. might survive well in many climatic conditions. Black et al. (2014) observed that ambient temperature affected Staphylococcus spp.; they exhibit some heat intolerance, suggesting that Staphylococcus spp. counts may increase in colder weather because of the increased survival in lower ambient temperatures. Similarly, Staphylococcus spp. counts experienced a slight decrease with increasing CBP temperature, but with no effect due to CBP moisture (Eckelkamp et al., 2016b). In period 2 of the present study, when ambient temperature increased and $\mathrm{CBP}$ temperature was higher in CBP-S than in CBP$\mathrm{FB}$, we detected similar counts in both treatments. In period 1, when ambient temperature decreased and CBP temperature was also higher in CBP-S than in CBP-FB, $S$. aureus counts were greater in CBP-S than 
in CBP-FB. When comparing periods within each treatment, higher $S$. aureus counts of CBP-S in period 1 agreed with the aforementioned reports, while higher $S$. aureus counts of CBP-FB in period 2 did not. This could be explained by CBP moisture results, where higher CBP moisture values could have limited $S$. aureus growth, which is in contrast with Eckelkamp et al. (2016b). However, it is possible that with worse weather conditions and pack performance, forest biomass could control S. aureus counts better than sawdust.

Bacillus bacteria is rarely the cause of mastitis (Brown and Scherer, 1957; Howell, 1972; Jones and Turnbull, 1981). However, Bacillus spores can survive pasteurization, reducing shelf life of milk (Jones and Turnbull, 1981; Griffiths, 1992). Bacillus spp. survive at a wide temperature range, with maximum growth temperatures ranging from 31 to $76^{\circ} \mathrm{C}$. This characteristic makes reduction of Bacillus spp. difficult while maintaining an active composting process because it thrives in environments where there are composting bacteria. Bacillus spp. counts increase at warmer CBP temperatures and lower C:N ratios, which occurr in summer (Shane et al., 2010). Lobeck et al. (2012) registered greater Bacillus spp. counts in summer and lesser Bacillus spp. counts in winter. Conversely, Eckelkamp et al. (2016b) reported that with increasing CBP temperature, Bacillus spp. counts within the pack decreased, whereas they increased with an increasing C:N ratio. In the present study, Bacillus spp. counts were greater in period 2 than in period 1 , when ambient and CBP temperature increased across the composting process and C:N ratio decreased only in CBP-S.

Yeast and fungi are normal flora of the soil and opportunistic colonizers of udder skin (Richard et al., 1980). Mycotic mastitis incidence is low, with Candida spp. as the most frequent pathogen (Kirk and Bartlett, 1986). No literature was found about yeasts and fungi counts in CBP dairy farms. High fungal spore concentrations, with a large variability and a wide spectrum of fungal species, were observed in cow barn bedding material (Hanhela et al., 1995). In the present study, yeasts and fungi counts were greater in CBP-FB than in CBP-S (5.61 and $4.62 \log _{10} \mathrm{cfu} / \mathrm{g}$, respectively; data not shown), and in period 1 (when CBP temperature was lower) than in period 2 (5.37 and $4.86 \log _{10} \mathrm{cfu} / \mathrm{g}$, respectively; data not shown). Whereas the yeasts and fungi counts grew from raw bedding material to CPB in the case of sawdust, this did not happen with the forest biomass (5.63 and $5.61 \log _{10} \mathrm{cfu} / \mathrm{g}$, respectively). This suggests that forest biomass could maintain the same yeasts and fungi counts across the composting process.

Dairy cattle spend 8 to $16 \mathrm{~h} / \mathrm{d}$ lying down, which emphasizes the importance of the lying surface to the animal (Haley et al., 2001). Increased lying times were observed when softer lying surfaces were available, particularly with large amounts of bedding (Krohn and Munksgaard, 1993). Optimizing the resting time of dairy cows enhances their welfare and productivity (Haley et al., 2001). Compost-bedded pack characteristics such as a larger resting area per animal and a softer bedding surface allow increased movement of cows because they provide more comfortable conditions for cows to lie down (Endres and Barberg, 2007). Increased lying times in CBP supported farmers' impressions of an improvement in cow comfort with this housing system (Eckelkamp et al., 2014). Endres and Barberg (2007) and Eckelkamp et al. (2014) reported lying times of $10.0 \pm 2.0 \mathrm{~h} / \mathrm{d}$ and $13.1 \pm 1.8 \mathrm{~h} / \mathrm{d}$ in $\mathrm{CBP}$, respectively. In the present study, the 2 treatments allowed similar values for resting times $(15.5 \pm$ $0.94 \mathrm{~h} / \mathrm{d}$ on average), and in both cases greater values when compared with the literature. This might be attributable to our experimental conditions, namely that nonlactating cows were individually allocated and were not milked. Kok et al. (2017) suggested that the dry period allows additional resting behavior, with lying times of $13.7 \mathrm{~h} / \mathrm{d}$. Furthermore, CBP allows cows to lie down in all 4 natural lying positions (Endres and Barberg, 2007). In the present study, both treatments reported similar percentages of lying time considering each lying position. These results were similar to those reported by Endres and Barberg (2007).

Time spent eating, ruminating, and drinking were similar between treatments, and we detected a tendency to be affected by period in eating and drinking behaviors. In period 1 , the colder period, cows tended to spend more time eating, possibly because digestion increases body basal temperature. Conversely, in period 2, the warmer period, cows tended to spend more time drinking, possibly because they had to cool down more. Dry matter intake and water consumption agreed numerically with these tendencies. Values for feeding behaviors (eating, ruminating, and drinking) were in the normal range established by Grant (2007).

Grooming behaviors are frequently observed in cattle (Reinhardt et al., 1978) and provide a range of benefits. Self-grooming is a flexible behavior which may be a good welfare indicator because it is influenced by environmental aspects, such as the type of bedding provided (Panivivat et al., 2004), and internal factors, such as disease (Borderas et al., 2008). Bedding material affects time spent self-grooming (Panivivat et al., 2004; Sutherland et al., 2017). Panivivat et al. (2004) described dairy calves performing more self-grooming when housed on rice hulls compared with long wheat straw or wood shavings. However, Sutherland et al. (2017) found that dairy calves reared on wood shavings spent more time performing self-grooming than 
those reared on other organic substrates. Bedding materials that prompted more self-grooming were those with higher moisture content in comparison with other materials, which suggested more stickiness to the coat of the calves (Panivivat et al., 2004; Sutherland et al., 2017). In the present study, cows in CBP-FB spent more time performing self-grooming than cows in CBP-S. Additionally, CBP-FB moisture $(66.4 \%)$ was numerically higher than CBP-S moisture (63.6\%), but only statistically greater in period 1 .

Cow hygiene depends on CBP moisture; cows are dirtier when CBP moisture is high because bedding material sticks more to the cow's coat. In the present study, we observed no differences in the dirty score between treatments, even though percentages of dirtiness in CBP-FB cows were numerically higher. Using a dichotomous scale or assessing specific body areas could statistically limit the dirtiness assessment. Polytomous systems used by Barberg et al. (2007b), Black et al. (2014), or Eckelkamp et al. (2016b) could make it possible to find some statistical differences.

Lying down and getting up movements of cattle can be used as a criterion for assessing the suitability of the lying surface (Lidfors, 1989). Cows spent more time to lie down on hard surfaces, such as concrete, because the lack of softness made the lying down movement less comfortable to perform (Krohn and Munksgaard, 1993; Herlin, 1997; Wechsler et al., 2000). Shepley et al. (2019) suggested a combination of fewer obstacles in the cow's environment, more space for the cow's lying area, and a more comfortable lying surface improved lying down and getting up movements. Compost dairy barns usually have a soft-cushioned lying surface that allows cows to lie down and get up without apparent discomfort. In the lying down movement in the present study, the longer time to lie down in cows on CBP-FB suggested a less comfortable lying surface than CBP-S. Time to lie down in CBP-S was in the range established as normal $(\leq 5.2 \mathrm{~s})$, while in CBP-FB it was in the lowest threshold of the range established as a moderate problem $(>5.2$ to $\leq 6.3 \mathrm{~s})$ according to the Welfare Quality Project (2009). Nevertheless, both treatments were far below the serious problem threshold $(>6.3 \mathrm{~s})$. Failed attempts to get up were greater in period 1, possibly because of the higher CBP moisture in this period, making it easier for cows to sink into the pack and, consequently, complicating the getting up movement. Intention time to lie down values and time to get up values recorded in the present study were within the wide range described by authors depending on housing system or bedding material (van Gastelen et al., 2011; Shepley et al., 2019). Complications observed in lying down and getting up movements appeared to be greater in CBP-FB and period 1, thus creating greater discomfort for cows, only when CBP performance was lower. This suggests that these complications may be eradicated by developing strategies to improve CBP performance in these conditions.

\section{CONCLUSIONS}

Based on the results of this experimental study, the alternative bedding material used, forest biomass, did not appear to work as well as sawdust in terms of CBP performance and cow comfort. However, forest biomass could be an interesting bedding material with regard to reducing microbiological counts of CBP. Further research is needed to confirm these results in a dairy barn system with lactating cows.

\section{ACKNOWLEDGMENTS}

This study was funded by the Spanish Ministry of Economy and Competitiveness and the European Regional Development Fund (Reference Project AGL201568373-C2-1-R, Madrid, Spain). The authors have not stated any conflicts of interest.

\section{REFERENCES}

AOAC. 1990. Official Methods of Analysis. 15th ed. AOAC, Washington, DC.

Barberg, A. E., M. I. Endres, and K. A. Janni. 2007b. Compost dairy barns in Minnesota: A descriptive study. Appl. Eng. Agric. 23:231238. https://doi.org/10.13031/2013.22606.

Barberg, A. E., M. I. Endres, J. A. Salfer, and J. K. Reneau. 2007a. Performance and welfare of dairy cows in an alternative housing system in Minnesota. J. Dairy Sci. 90:1575-1583. https://doi.org/ 10.3168/jds.S0022-0302(07)71643-0.

Barkema, H. W., Y. H. Schukken, and R. N. Zadoks. 2006. Invited review: The role of cow, pathogen, and treatment regimen in the therapeutic success of bovine Staphylococcus aureus mastitis. J. Dairy Sci. 89:1877-1895. https://doi.org/10.3168/jds.S0022 -0302(06)72256-1.

Bewley, J. M., J. L. Taraba, D. McFarland, P. Garrett, R. Graves, B. Holmes, D. Kammel, J. Porter, J. Tyson, S. Weeks, and P. Wright. 2013. Guidelines for managing compost bedded-pack barns. The Dairy Practices Council. Accessed June 4, 2014. https://www .dairypc.org/catalog/guidelines-for-managing-compost-bedded -pack-barns.

Black, R. A., J. L. Taraba, G. B. Day, F. A. Damasceno, and J. M. Bewley. 2013. Compost bedded pack dairy barn management, performance, and producer satisfaction. J. Dairy Sci. 96:8060-8074. https://doi.org/10.3168/jds.2013-6778.

Black, R. A., J. L. Taraba, G. B. Day, F. A. Damasceno, M. C. Newman, K. A. Akers, C. L. Wood, K. J. McQuerry, and J. M. Bewley. 2014. The relationship between compost bedded pack performance, management, and bacterial counts. J. Dairy Sci. 97:2669-2679. https://doi.org/10.3168/jds.2013-6779.

Borderas, T. F., A. M. de Passillé, and J. Rushen. 2008. Behavior of dairy calves after a low dose of bacterial endotoxin. J. Anim. Sci. 86:2920-2927. https://doi.org/10.2527/jas.2008-0926.

Bramley, A. J., L. S. Cullor, R. J. Erskine, L. K. Fox, R. S. Harmon, J. S. Hogan, S. C. Nickerson, S. P. Oliver, and L. M. Sordillo. 1996. Current Concepts of Bovine Mastitis. 4th ed. National Mastitis Council, Madison, WI 
Brown, R. W., and R. K. Scherer. 1957. A report on two cases of acute mastitis caused by Bacillus cereus. Cornell Vet. 47:226-240.

Eberhart, R. J. 1984. Coliform mastitis. Vet. Clin. North Am. Large Anim. Pract. 6:287-300. https://doi.org/10.1016/S0196 -9846(17)30023-X.

Eckelkamp, E. A., C. N. Gravatte, C. O. Coombs, and J. M. Bewley. 2014. Case study: Characterization of lying behavior in dairy cows transitioning from a freestall barn with pasture access to a compost bedded pack barn without pasture access. Prof. Anim. Sci. 30:109-113. https://doi.org/10.15232/S1080-7446(15)30092-9.

Eckelkamp, E. A., J. L. Taraba, K. A. Akers, R. J. Harmon, and J. M. Bewley. 2016a. Sand bedded freestall and compost bedded pack effects on cow hygiene, locomotion, and mastitis indicators. Livest. Sci. 190:48-57. https://doi.org/10.1016/j.livsci.2016.06.004.

Eckelkamp, E. A., J. L. Taraba, K. A. Akers, R. J. Harmon, and J. M. Bewley. 2016b. Understanding compost bedded pack barns: Interactions among environmental factors, bedding characteristics, and udder health. Livest. Sci. 190:35-42. https://doi.org/10.1016/ j.livsci.2016.05.017.

Endres, M. I., and A. E. Barberg. 2007. Behavior of dairy cows in an alternative bedded-pack housing system. J. Dairy Sci. 90:41924200. https://doi.org/10.3168/jds.2006-751.

Fernández, A., E. Mainau, X. Manteca, A. Siurana, and L. Castillejos. 2020. Impacts of compost bedded pack barns on the welfare and comfort of dairy cows. Animals (Basel) 10:431. https://doi.org/10 $.3390 /$ ani10030431

Fregonesi, J. A., and J. D. Leaver. 2001. Behaviour, performance and health indicators of welfare for dairy cows housed in strawyard or cubicle systems. Livest. Prod. Sci. 68:205-216. https://doi.org/10 .1016/S0301-6226(00)00234-7.

Galama, P. J., S. Bokma, H. J. van Dooren, W. Ouweltjes, M. Smits, and F. Driehuis. 2011. Prospects for Bedded Pack Barns for Dairy Cattle. Wageningen UR Livestock Research, Lelystad, the Netherlands.

Grant, R. 2007. Taking advantage of natural behavior improves dairy cow performance. Pages 225-236 in Proc. Western Dairy Management Conf., Reno, NV.

Griffiths, M. W. 1992. Bacillus cereus in liquid milk and other milk products. Bull. Int. Dairy Fed. 275:36-39.

Haley, D. B., A. M. de Passillé, and J. Rushen. 2001. Assessing cow comfort: Effects of two floor types and two tie stall designs on the behaviour of lactating dairy cows. Appl. Anim. Behav. Sci. 71:105-117. https://doi.org/10.1016/S0168-1591(00)00175-1.

Hanhela, R., K. Louhelainen, and A. L. Pasanen. 1995. Prevalence of microfungi in Finnish cow barns and some aspects of the occurrence of Wallemia sebi and Fusaria. Scand. J. Work Environ. Health 21:223-228. https://doi.org/10.5271/sjweh.31 https://doi .or/10.5271/sjweh.31.

Hardie, J. M., and R. A. Whiley. 1995. The genus Streptococcus. Pages 55-124 in The Lactic Acid Bacteria: The Genera of Lactic Acid Bacteria. Vol. 2. B. J. B. Wood and W. H. Holzapfel, ed. Blackie Academic and Professional, London, UK.

Herlin, A. H. 1997. Comparison of lying area surfaces for dairy cows by preference, hygiene and lying down behaviour. Swed. J. Agric. Res. 27:189-196

Hogan, J. S., and K. L. Smith. 1997. Bacteria counts in sawdust bedding. J. Dairy Sci. 80:1600-1605. https://doi.org/10.3168/jds .S0022-0302(97)76090-9.

Hogan, J. S., K. L. Smith, K. H. Hoblet, D. A. Todhunter, P. S. Schoenberger, W. D. Hueston, D. E. Pritchard, G. L. Bowman, L. E. Heider, B. L. Brockett, and H. R. Conrad. 1989. Bacterial counts in bedding materials used on nine commercial dairies. J. Dairy Sci. 72:250-258. https://doi.org/10.3168/jds.S0022 $-0302(89) 79103-7$.

Howell, D. 1972. Survey on mastitis caused by environmental bacteria. Vet. Rec. 90:654-657. https://doi.org/10.1136/vr.90.23.654.

Janni, K. A., M. I. Endres, J. K. Reneau, and W. W. Schoper. 2007. Compost dairy barn layout and management recommendations. Appl. Eng. Agric. 23:97-102. https://doi.org/10.13031/2013 .22333 .
Jones, T. O., and P. C. Turnbull. 1981. Bovine mastitis caused by Bacillus cereus. Vet. Rec. 108:271-274. https://doi.org/10.1136/ vr.108.13.271.

Kirk, J. H., and P. C. Bartlett. 1986. Bovine mycotic mastitis. Acta Vet. Scand. 8:106-111.

Klaas, I. C., B. Bjerg, S. Friedmann, and D. Bar. 2010. Cultivated barns for dairy cows: An option to promote cattle welfare and environmental protection in Denmark? Dan. Vet. 93:20-29.

Kok, A., R. J. van Hoeij, B. J. Tolkamp, M. J. Haskell, A. T. M. van Knegsel, I. J. M. de Boer, and E. A. M. Bokkers. 2017. Behavioural adaptation to a short or no dry period with associated management in dairy cows. Appl. Anim. Behav. Sci. 186:7-15. https://doi .org/10.1016/j.applanim.2016.10.017.

Krohn, C. C., and L. Munksgaard. 1993. Behaviour of dairy cows kept in extensive (loose housing/pasture) or intensive (tie stall) environments. II. Lying and lying-down behaviour. Appl. Anim. Behav. Sci. 37:1-16. https://doi.org/10.1016/0168-1591(93)90066-X.

Landis, J. R., and G. G. Koch. 1977. An application of hierarchical kappa-type statistics in the assessment of majority agreement among multiple observers. Biometrics 33:363-374. https://doi.org/ $10.2307 / 2529786$

Lidfors, L. 1989. The use of getting up and lying down movements in the evaluation of cattle environments. Vet. Res. Commun. 13:307324. https://doi.org/10.1007/BF00420838.

Littell, R. C., P. R. Henry, and C. B. Ammerman. 1998. Statistical analysis of repeated measures data using SAS procedures. J Anim. Sci. 76:1216-1231. https://doi.org/10.2527/1998.7641216x.

Lobeck, K. M., M. I. Endres, K. A. Janni, S. M. Godden, and J. Fetrow. 2012. Environmental characteristics and bacterial counts in bedding and milk bulk tank of low profile cross-ventilated, naturally ventilated, and compost bedded pack dairy barns. Appl. Eng. Agric. 28:117-128. https://doi.org/10.13031/2013.41280.

NRAES-54. 1992. On-Farm Composting Handbook. R. Rynk, ed Northeast Regional Agricultural Engineering Service, Ithaca, NY.

NRC. 1971. A Guide to Environmental Research on Animals. Natl. Acad. Sci. Washington, DC

Panivivat, R., E. B. Kegley, J. A. Pennington, D. W. Kellogg, and S. L. Krumpelman. 2004. Growth performance and health of dairy calves bedded with different types of materials. J. Dairy Sci. 87:3736-3745. https://doi.org/10.3168/jds.S0022-0302(04)73512 -2 .

Petzen, J., C. Wolfanger, J. Bonhotal, M. Schwarz, T. Terry, and N. Youngers. 2009. Case study: Eagleview compost dairy barn. Cornell Cooperative Extension of Wyoming County, Warsaw, NY, Accessed Aug. 4, 2014. https://hdl.handle.net/1813/44658.

Reinhardt, V., F. M. Mutiso, and A. Reinhardt. 1978. Social behaviour and social relationships between female and male prepubertal bovine calves (Bos indicus). Appl. Anim. Ethol. 4:43-54. https:// doi.org/10.1016/0304-3762(78)90092-5.

Richard, J. L., J. S. McDonald, R. E. Fichtner, and A. J. Anderson. 1980. Identification of yeasts from infected bovine mammary glands and their experimental infectivity in cattle. Am. J. Vet. Res. 41:1991-1994.

Roberson, J. R.. L. K. Fox, D. D. Hancock, J. M. Gay, and T. E. Besser. 1994. Ecology of Staphylococcus aureus isolated from various sites on dairy farms. J. Dairy Sci. 77:3354-3364. https://doi .org/10.3168/jds.S0022-0302(94)77277-5.

Shane, E. M., M. I. Endres, and K. A. Janni. 2010. Alternative bedding materials for compost bedded pack barns in Minnesota: A descriptive study. Appl. Eng. Agric. 26:465-473. https://doi.org/ $10.13031 / 2013.29952$

Shepley, E., G. Obinu, T. Bruneau, and E. Vasseur. 2019. Housing tiestall dairy cows in deep-bedded pens during an 8-week dry period: Effects on lying time, lying postures, and rising and lying-down behaviors. J. Dairy Sci. 102:6508-6517. https://doi.org/10.3168/ jds.2018-15859.

Stentiford, E. I. 1996. Composting control: Principles and practice. Pages 49-59 in The Science of Composting, Part 1. M. de Bertoldi, P. Sequi, B. Lemmes, and T. Papi, ed. Blackie Academic and Professional, London, UK. 
Sutherland, M. A., G. M. Worth, C. Cameron, C. M. Ross, and D. Rapp. 2017. Health, physiology, and behavior of dairy calves reared on 4 different substrates. J. Dairy Sci. 100:2148-2156. https://doi .org/10.3168/jds.2016-12074.

van Gastelen, S., B. Westerlaan, D. J. Houwers, and F. J. C. M. van Eerdenburg. 2011. A study on cow comfort and risk for lameness and mastitis in relation to different types of bedding materials. J. Dairy Sci. 94:4878-4888. https://doi.org/10.3168/jds.2010-4019.

Van Soest, P. J., J. B. Robertson, and B. A. Lewis. 1991. Methods for dietary fiber, neutral detergent fiber and nonstarch polysaccharides in relation to animal nutrition. J. Dairy Sci. 74:3583-3597. https://doi.org/10.3168/jds.S0022-0302(91)78551-2.

Vandenbosch, L. L., D. Y. C. Fung, and M. Widomski. 1973. Optimum temperature for enterotoxin production by Staphylococcus aureus S-6 and 137 in liquid medium. Appl. Microbiol. 25:498-500. https: //doi.org/10.1128/AEM.25.3.498-500.1973.

Ward, W. R., J. W. Hughes, W. B. Faull, P. J. Cripps, J. P. Sutherland, and J. E. Sutherst. 2002. Observational study of temperature, moisture, $\mathrm{pH}$ and bacteria in straw bedding, and faecal con- sistency, cleanliness and mastitis in cows in four dairy herds. Vet. Rec. 151:199-206. https://doi.org/10.1136/vr.151.7.199.

Wechsler, B., J. Schaub, K. Friedli, and R. Hauser. 2000. Behavior and leg injuries in dairy cows kept in cubicle systems with straw bedding or soft lying mats. Appl. Anim. Behav. Sci. 69:189-197. https: //doi.org/10.1016/S0168-1591(00)00134-9.

Welfare Quality Project. 2009. Welfare Quality Assessment Protocol for Cattle. Welfare Quality Consortium, Lelystad, the Netherlands.

Zdanowicz, M., J. A. Shelford, C. B. Tucker, D. M. Weary, and M. A. G. von Keyserlingk. 2004. Bacterial populations on teat ends of dairy cows housed in free stalls and bedded with either sand or sawdust. J. Dairy Sci. 87:1694-1701. https://doi.org/10.3168/jds S0022-0302(04)73322-6.

Zucconi, F., and M. de Bertoldi. 1987. Compost specifications for the production and characterization of compost from municipal solid waste. Pages 30-50 in Compost: Production, Quality and Use. M. Bertoldi, M. P. Ferranti, P. L'Hermite, and F. Zucconi, ed. Elsevier, Barking, UK. 